\title{
Jungel Nirvana
}

\author{
Katrine Damgård Finsnes \\ knirken_f@yahoo.com \\ Akuttklinikken \\ Stavanger universitetssjukehus \\ Postboks 8100 \\ 4068 Stavanger \\ Monica Elisabeth Iversen-Tennøe \\ Varteig legesenter \\ Greåker
}

«Men wanted for hazardous journey. Small wages, bitter cold, long months of complete darkness. Constant journey, safe return doubtful. Honor and recognition in case of success.»

Denne annonsen plasserte Ernest Shackleton (1874-1922) i en av Londons aviser i august 1914. 5000 mennesker svarte (1). Ordet ekspedisjon får en til å tenke på Christopher Columbus og James Cook som fant nye land og veier, eller Fridtjof Nansens tur over Grønland. I dag kan det også bety en forskningsekspedisjon, en filmtur eller ekstremturisme. Dette fører til et voksende behov for ekspertise innenfor ekspedisjonsmedisin - en type prehospital medisin.

\section{Ekspedisjonsmedisin}

Ekspedisjonsmedisin defineres som prehospital medisin der det tar mer enn én time à transportere pasienten til nærmeste sted med definitiv behandling, og ofte tar det dager eller uker (2). Problemstillingene er de samme som for prehospital medisin ellers, men i større grad; vanskelig tilgang til pasienten, begrenset utstyr og ekstreme omgivelser. I flere land, bl.a. England og USA, er ekspedisjonsmedisin (wilderness medicine) en egen subspesialitet innenfor akuttmedisin (emergency medicine). Den internasjonalt aktive organisasjonen Wilderness Medical Society driver bl.a. med utdanning og forskning innenfor området, publiserer et månedlig tidsskrift og organiserer internasjonale kongresser om ekspedisjonsmedisin (3). Tidsskriftet Wilderness Medicine (WM) Magazine har kommet ut hvert kvartal siden 1982. Den første av de årlige verdenskongressene ble avholdt i USA i 1991, og det finnes etter hvert rikelig med litteratur og forskning innenfor dette området. Ekspedisjonsmedisin omfatter egentlig det meste innenfor medisinens verden, men kjerneområdene er sportsmedisin, tropemedisin, ekspedisjonsferdigheter (navigering, vannrensing, hygiene osv.), samt medisin som er spesifikk for visse miljøer (dykke-/marinmedisin, klatre-/høydemedisin, polarmedisin, jungelmedisin og ørkenmedisin). Organisasjonen Expedition Medicine er en av dem som tilbyr kurs i ekspedisjonsmedisin over hele verden (4). Jeg deltok nylig på et slikt kurs i jungelmedisin i Costa Rica.

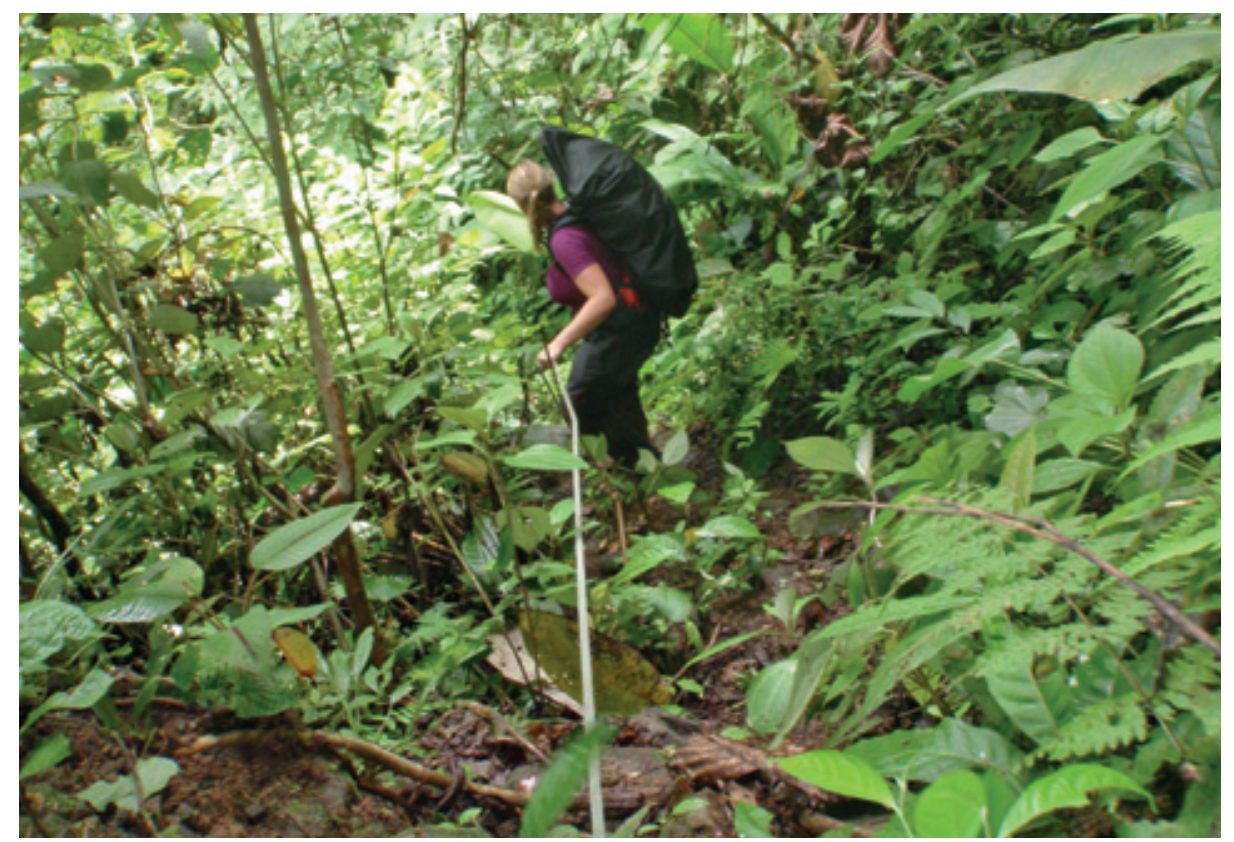

Bratt og glatt terreng krevde bruk av tau. Alle foto Katrine Damgård Finsnes

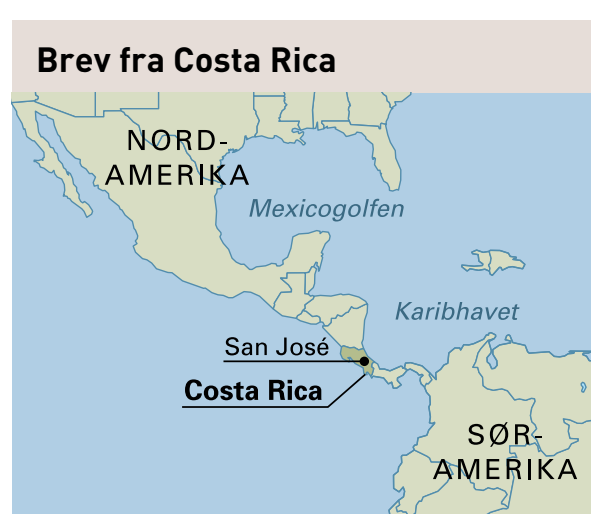

\section{Jungelekspedisjon}

Costa Rica er et nydelig lite land fylt av tykk, nærmest ugjennomtrengelig regnskog som er oppstykket av ville elvestryk. For å ta oss frem i denne utemmede naturen ble vi nødt til å ta machetene i bruk. Gruppen på 20 leger og 1 paramedisiner (paramedic) raftet inn til basecamp gjennom heftige stryk.

Under uken i jungelen ble det fokusert på ledelse, samarbeid og overlevelsesferdigheter. Fra basen tok vi flere ekskursjoner i bratt terreng i tykk regnskog. Underveis fikk vi øvd oss på praktiske ferdigheter. Blant annet lærte vi å rense vann, hente ut skadede, improvisere bårebygging og håndtere slangebitt.

Ikke overraskende var det en våt opplevelse midt i regntiden. Om kvelden skiftet vi til vårt andre sett med klær som etter planen skulle være tørre (om jeg bare hadde hengt opp presenningen korrekt over hengekøyen).

Målet til kurslederne var at vi skulle oppnå «jungel nirvana», dvs. en tilstand der man trives i noe av verdens tøffeste og ubehageligste omgivelser. Faktisk nådde jeg nesten denne tilstanden - der man er helt fornøyd med å være konstant våt og gjørmete og synes at tarantellaer og skorpioner er tilnærmet søte. Vi inntok gode middager med «gallo pinto» (ris og bønner) og deilig, fersk ananas før kveldens undervisning. De erfarne ekspdisjonslegene og -lederne holdt da interaktive foredrag om temaer som tropesykdommer og hvordan organisere en «casevac» (casualty evacuation), dvs. evakuering av skadet/pasient.

\section{Praktisk øvelse}

Teori ble satt ut i praksis - i mye større grad enn vi hadde ant. Vi forlot basen og dro på en mindre ekspedisjon. En av dagene slo vi 


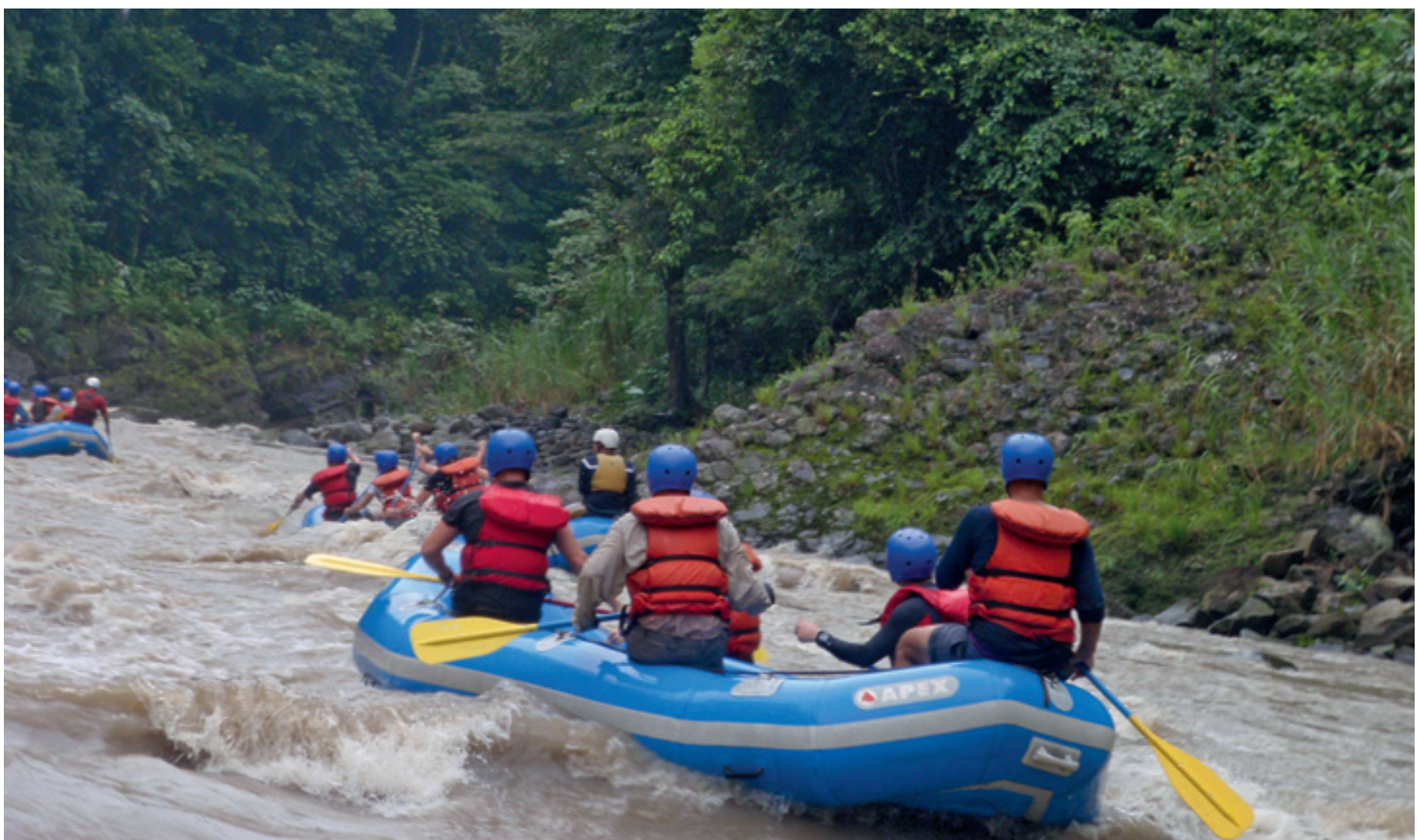

Vi raftet inn og ut fra basecamp gjennom den tykke jungelen

leir 2100 m høyere enn basens nivå, etter en strabasiøs tur oppover. Retningslinjer for organisering av leirsted ble fulgt; plassering i forhold til vann, latrine, fellesområder osv. Det eneste vi ikke klarte å etterleve, var regelen om et trygt leirsted, dvs. en passende avstand fra farlige dyrs drikkevann, utrygg grunn eller liknende. Vi hadde endelig fått $i$ gang et bål av våt ved da vi ble gjenstand for noen afrikanske biers indignasjon. Denne rasen er kjent for sin aggres-

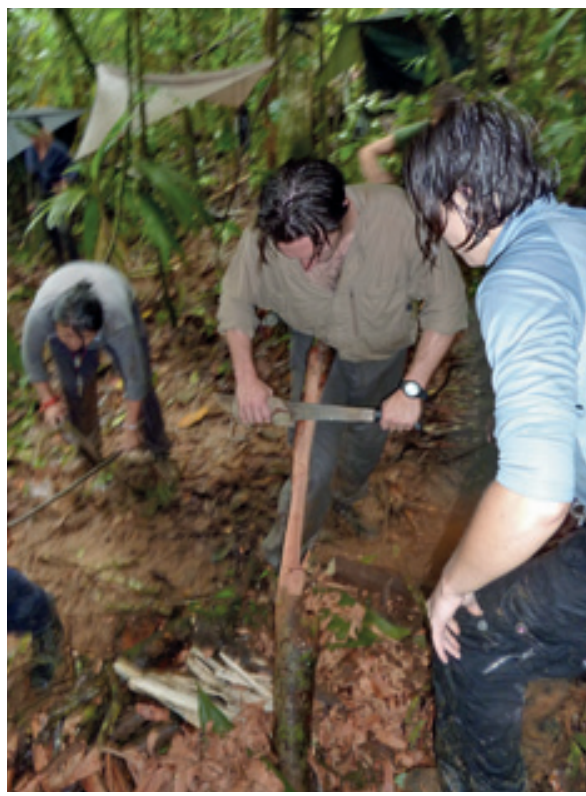

Det er ikke lett å tenne bål med våt ved sive, territorielle atferd. Kombinert med det faktum at de har en gift som ofte fremkaller anafylaksi, har dette gitt dem navnet «killer bees» på engelsk. En av kursdeltakerne ble stukket og utviklet anafylaktisk sjokk. Leger på tur har selvsagt med adrenalin, og dette ble gitt intramuskulært sammen med intravenøse steroider og antihistamin. Til tross for dette var hun svært dårlig, og det ble tidlig klart at hun trengte sykehusinnleggelse.

Den aktuelle leiren ga en ekstra utfordring i forhold til evakuering av pasienten fordi terrenget var bratt, gjørmete og med tett skog. I tillegg var det blitt mørkt og dermed yndlingstiden til mange av jungelens giftige skapninger. Et team bestående av ni leger og en tolk ble raskt valgt ut. En av legene hadde ansvaret for det medisinske, og de resterende var med som bærere. Tolken gikk fremst og hadde ansvaret for navigeringen. De fikk det vi hadde av vann, kjeks og adrenalin og kom seg av gårde i løpet av fem minutter. Det første strekket kunne pasienten heldigvis transporteres i en improvisert «piggyback»båre. Dette er en konstruksjon av rep som gjorde at hun kunne henge som en ryggsekk gjennom de bratteste partiene der vi hadde klatret opp med tau. Underveis fikk hun ufrie luftveier grunnet lavt bevissthetsnivå, men responderte heldigvis bra på kjevetak. For å opprettholde dette under transporten måtte en alminnelig båre konstrueres av tømmerstokker og t-skjortene til teamet.
Hun fikk flere doser med adrenalin, totalt $3 \mathrm{mg}$, men mesteparten av tiden var hun gråblek i huden med Glasgows komaskår rundt 7, og det var kun carotispulsen som var følbar. Tre timer senere, etter å ha gått på line over elven, var gruppen fremme ved et sted der en firehjulstrekker kunne komme til. 7,5 timer senere var hun fremme ved et sykehus, og ett døgn senere kunne hun utskrives i beste velgående.

Trass i, eller kanskje nettopp på grunn av, denne dramatiske episoden ga kurset mersmak. Hvis man liker reiser og utendørsliv, er ekspedisjonsmedisin den perfekte måte å kombinere jobb og hobby.

Pasienten har gitt samtykke til at artikkelen blir publisert.

Oppgitte interessekonflikter: Ingen

Litteratur

1. Hudson S, Knox C. Expedition and wilderness medicine. London: Winston Churchill, 1998.

2. Wikipedia. Wilderness medicine. http://en. wikipedia.org/wiki/Wilderness_medicine (28.12.2009).

3. The Wilderness Medical Society. www.wms.org (28.12.2009).

4. Expedition Medicine. www.expeditionmedicine.co.uk/ (28.12.2009).

Manuskriptet ble mottatt 29.1. 2010 og godkjent 19.8. 2010. Medisinsk redaktør Mette Sagsveen. 